\title{
First report of Bickerstaff's brainstem encephalitis caused by Salmonella Dublin: a case report
}

\author{
Jiangbo Xie ${ }^{\dagger}$, Tingting Zhang ${ }^{\dagger}$ and Tao Liu ${ }^{*}$
}

\begin{abstract}
Background: Diseases caused by nontyphoid Salmonella can range from mild, to self-limiting gastroenteritis and severe invasive infection. Relatively rarely, Salmonella may cause severe encephalopathy.

Case presentation: We report a suspected case of Bickerstaff's brainstem encephalitis caused by Salmonella Dublin. A young man presented with impaired consciousness, ataxia, dysarthria, limb weakness, and restricted eyeball abduction. His clinical symptoms were consistent with Bickerstaff's brainstem encephalitis.

Conclusions: This is the first case report of Bickerstaff's brainstem encephalitis caused by Salmonella Dublin in the literature. After treatment, he recovered and was discharged. Early antibiotic treatment of sepsis may control the disease and avoid serious encephalopathy.
\end{abstract}

Keywords: Bickerstaff's brainstem encephalitis, Salmonella Dublin, Case report

\section{Background}

Most Salmonella species that are pathogenic in humans belong to Salmonella Enteritidis. Salmonella Typhi and Salmonella Typhi A are the pathogens that cause typhoid fever, a potentially fatal disease. Diseases caused by nontyphoid Salmonella can range from mild to selflimiting gastroenteritis and severely invasive infections. Salmonella may cause severe encephalopathy, though it is relatively rare. We report a case of Bickerstaff's brainstem encephalitis (BBE) caused by Salmonella Dublin. Cerebrospinal fluid (CSF) examination on admission was normal, as was a brain magnetic resonance imaging (MRI) scan. An anti-GQ1b antibody test was negative, and CSF protein/cell dissociation occurred 20 days after admission. During hospitalization, the patient was treated with intravenous immunoglobulin (IVIg) therapy and then discharged.

\footnotetext{
* Correspondence: 344342312@qq.com
${ }^{+}$Jiangbo Xie and Tingting Zhang are co-first authors.

* Correspondence: 344342312@qq.com
†Jiangbo Xie and Tingting Zhang are co-first authors.

Department of Neurology, Weifang Traditional Chinese Hospital, Weifang, China
}

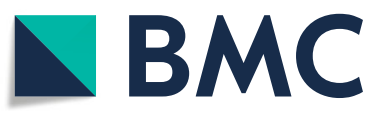

(c) The Author(s). 2021 Open Access This article is licensed under a Creative Commons Attribution 4.0 International License, which permits use, sharing, adaptation, distribution and reproduction in any medium or format, as long as you give appropriate credit to the original author(s) and the source, provide a link to the Creative Commons licence, and indicate if changes were made. The images or other third party material in this article are included in the article's Creative Commons licence, unless indicated otherwise in a credit line to the material. If material is not included in the article's Creative Commons licence and your intended use is not permitted by statutory regulation or exceeds the permitted use, you will need to obtain permission directly from the copyright holder. To view a copy of this licence, visit http://creativecommons.org/licenses/by/4.0/. The Creative Commons Public Domain Dedication waiver (http://creativecommons.org/publicdomain/zero/1.0/) applies to the data made available in this article, unless otherwise stated in a credit line to the data.
A 33-year-old man developed diarrhoea 1 day after eating fried pork with chili and fever the next day, with a body temperature of $40^{\circ} \mathrm{C}$. The results of blood and faecal cultures were positive for Salmonella Dublin. Influenza A virus, influenza B virus, Mycoplasma pneumoniae, Chlamydia pneumoniae, respiratory syncytial virus, Haemophilus influenzae, varicella-zoster virus, Legionella, Campylobacter and SARS$\mathrm{CoV}-2$ tests were all negative. The patient developed drowsiness after 3 days, with gradual weakening of the limbs, dysarthria, binocular abduction paralysis, and ataxia. His brain MRI scan was normal. After 5 days, the patient could not raise his limbs. These symptoms were accompanied by liver function damage and myocardial damage. After 7 days, the patient still had weakness of the limbs and dysarthria. However, as other indicators improved, he was transferred from the Intensive Care Unit ward to the Neurology ward. Physical examination of the nervous system mainly showed flaccid paralysis of the limbs, disappearance of the bilateral tendon reflex, inability to speak, ataxia (bilateral limb paralysis limited the ability to assess gait), and positive bilateral 
Babinski signs. At that time, lumbar puncture results for intracranial pressure, CSF protein, and CSF cell number were normal, and the CSF was cultured for 3 days with no bacterial growth. On re-examination, the brain MRI and cervical MRI were normal. As BBE was suspected clinically, IVIg therapy $(0.4 \mathrm{~g} / \mathrm{kg})$ was given for 5 days, but the patient's symptoms did not improve significantly. Twenty days after admission, lumbar puncture examination showed that the protein content had increased by $0.86 \mathrm{~g} / \mathrm{L}$ (the normal range is $0.08-0.43 \mathrm{~g} / \mathrm{L}$ ); the cell number was normal (the number of nucleated cells was 6 , normal range $0-8$; the red blood cell count was 0), CSF and serum anti-GQ1b antibody was negative, and CSF anti-MOG, anti-AQP4, and anti-MBP antibodies were all negative. The results of electrophysiological examination were normal (14 days and 60 days after onset). Considering no obvious improvement, at 21 days, he was given IVIg again at the same dose for 5 days. The patient's symptoms gradually improved, and he was able to start walking on his own. His limb collateral movement was significantly better than before, his eye movement was normal, and his voice was low. The patient's speech could be heard clearly, and he was given speech rehabilitation training. After 3 months, the patient could walk $10 \mathrm{~m}$ without assistance but was unable to run (the grade of the GBS disability scale was 2) [1]. His speech also returned to normal.

\section{Discussion and conclusion}

Salmonella causes a tremendous global burden of disease [2]. It is estimated that 535,000 cases of invasive nontyphoid Salmonella infection occur globally each year [3]. The clinical manifestations caused by human salmonellosis are complicated; they can be divided according to severity into gastroenteritis, typhoid fever, sepsis, local purulent infection, and asymptomatic infection. Nontyphoid Salmonella mainly causes self-limiting diarrhoea in healthy individuals, with mild symptoms; blood-borne or focal infections are rare and mostly occur in individuals with specific risk factors [4]. Salmonella Dublin is the main pathogen causing Salmonella disease in sheep, cattle, and other animals, though it rarely causes severe symptoms in humans [5]. Salmonella Dublin belongs to Group D. Clinically, only $1 \%$ of isolates are isolated from faeces; approximately $40 \%$ are isolated from blood. The mortality rate is $20 \%$ [6]. This case is the first report of BBE caused by Salmonella Dublin. There is a previous report of BBE caused by typhoid fever and Salmonella Paratyphi A $[7,8]$.

BBE comprises a group of autoimmune diseases characterized by acute ophthalmoplegia, ataxia, disturbance of consciousness and/or pyramidal tract signs, with an annual incidence rate of less than 0.1 per 100,000 [9]. Although the pathogenesis is still not fully understood, most patients have a history of preinfection with Guillain-Barré syndrome and Miller-
Fisher syndrome, with symptoms such as upper respiratory tract infection and diarrhoea. It has been reported that the main pathogenic microorganisms of BBE are Mycoplasma pneumoniae [10-12], Campylobacter jejuni [13, 14], cytomegalovirus [15], varicellazoster virus [7], and Epstein-Barr virus [8] (Table 1). As no evidence of Campylobacter infection was found in our patient's blood or faeces during hospitalization, we excluded BBE caused by Campylobacter infection. The results of blood culture and faecal culture in our case indicated Salmonella Dublin infection. The patient was admitted to the hospital to consider sepsis caused by Salmonella Dublin, after which symptoms of encephalopathy appeared. The patient's typical clinical manifestations and CSF protein/cell dissociation supported the diagnosis of BBE.

Studies have found that anti-GQlb IgG antibodies with the same specificity are prevalent in the serum of $\mathrm{BBE}$ patients, and approximately $66 \%$ of patients test positive for anti-GQlb IgG antibodies [18]. The titre typically reaches its peak at the beginning of the disease and decreases over time. Notably, there may be other unknown mechanisms or autoimmune targets responsible [18]. Nevertheless, the anti-GQlb IgG antibody test was negative in our case, which may be related to the late examination of the patient.

In most cases of BBE, CSF protein/cell dissociation occurs within 4 weeks of disease development. However, in a small number of cases, the disease is not accompanied by elevated protein levels [12, 13, 15-17]. Brain MRI examination reveals abnormal findings in approximately one-third of BBE patients, with long T2 signal lesions in the brainstem, thalamus, cerebellum, and white matter [18]. Studies have shown that abnormal MRI results are due to vasogenic cerebral oedema [19]. However, the MRI examination in the present case showed no abnormalities.

In our case, the results of blood and stool cultures indicated Salmonella Dublin infection, and the patient was admitted to the hospital to consider sepsis caused by this organism. Encephalopathy symptoms appeared days later. The current research mechanism include destruction of the blood-brain barrier via upregulated expression of autocrine MMP-9 in human brain microvascular endothelial cells [20].

Effective treatment for BBE involves immunotherapy, such as steroids, plasma exchange, and IVIg [18, 21]. However, dexamethasone is the first choice for neurological complications caused by Salmonella and Salmonella encephalopathy. Therefore, the clinical recognition of BBE and Salmonella encephalopathy is particularly important, which determines the different treatment options. In this case, the patient's symptoms gradually improved after IVIg therapy. 
Table 1 Summary of the characteristics of Bickerstaff's brainstem encephalitis-related cases reported in the literature

\begin{tabular}{|c|c|c|c|c|c|c|c|c|}
\hline Publisher & $\begin{array}{l}\text { Publication } \\
\text { time }\end{array}$ & Country & Infection types & Gender & Age & $\begin{array}{l}\text { GQ1blgG } \\
\text { antibody }\end{array}$ & $\mathrm{CSF}^{\mathrm{a}}$ test & Imaging examination \\
\hline $\begin{array}{l}\text { Kikuchi,M } \\
\text { et al. [10] }\end{array}$ & 1997 & Japan & $\begin{array}{l}\text { Mycoplasma } \\
\text { pneumoniae }\end{array}$ & male & 7 & positive & $\begin{array}{l}\text { Protein cell } \\
\text { dissociation }\end{array}$ & T2 high signal around aqueduct \\
\hline $\begin{array}{l}\text { Steer } \\
\text { AC.et al. } \\
{[11]}\end{array}$ & 2006 & Japan & $\begin{array}{l}\text { Mycoplasma } \\
\text { pneumoniae }\end{array}$ & male & 11 & positive & $\begin{array}{l}\text { Protein and } \\
\text { cell normal }\end{array}$ & $\begin{array}{l}\text { MRI showed diffuse meningeal enhancement } \\
\text { and patchy hyperintensity in the spinal cord }\end{array}$ \\
\hline $\begin{array}{l}\text { Hussain AM } \\
{[13]}\end{array}$ & 2007 & UK & $\begin{array}{l}\text { Campylobacter } \\
\text { jejuni }\end{array}$ & male & 54 & negative & $\begin{array}{l}\text { Protein and } \\
\text { cell normal }\end{array}$ & T2 hyperintense area in the brainstem \\
\hline $\begin{array}{l}\text { Masahiro } \\
\text { Mori et al. } \\
{[14]}\end{array}$ & 2008 & Japan & $\begin{array}{l}\text { Campylobacter } \\
\text { jejuni }\end{array}$ & female & 26 & positive & $\begin{array}{l}\text { Protein cell } \\
\text { dissociation }\end{array}$ & Not done \\
\hline $\begin{array}{l}\text { Kanzaki A } \\
\text { et al. [15] }\end{array}$ & 1995 & Japan & Cytomegalovirus & female & 17 & positive & $\begin{array}{l}\text { Protein and } \\
\text { cell normal }\end{array}$ & Brain $\mathrm{CT}$ and $\mathrm{MRI}$ were normal \\
\hline $\begin{array}{l}\text { Tagawa } Y, \\
\text { et a [7] }\end{array}$ & 2000 & Japan & $\begin{array}{l}\text { Varicella zoster } \\
\text { virus }\end{array}$ & male & 59 & positive & $\begin{array}{l}\text { Protein cell } \\
\text { dissociation }\end{array}$ & No abnormality was found \\
\hline Rho, YI [8] & 2014 & Korea & $\begin{array}{l}\text { Epstein Barr } \\
\text { virus }\end{array}$ & male & 2 & negative & $\begin{array}{l}\text { Protein and } \\
\text { cell normal }\end{array}$ & MRI was normal \\
\hline $\begin{array}{l}\text { Wali } \\
\text { GM.et al. } \\
{[16]}\end{array}$ & 1991 & India & Salmonella typhi & male & 14 & $\begin{array}{l}\text { Not } \\
\text { recorded }\end{array}$ & $\begin{array}{l}\text { Protein and } \\
\text { cell normal }\end{array}$ & Brain CT was normal \\
\hline $\begin{array}{l}\text { Bun Sheng } \\
\text { et al. [17] }\end{array}$ & 2010 & $\begin{array}{l}\text { Hong } \\
\text { Kong, } \\
\text { China }\end{array}$ & $\begin{array}{l}\text { Salmonella } \\
\text { Paratyphi A }\end{array}$ & female & 28 & positive & $\begin{array}{l}\text { Protein and } \\
\text { cell normal }\end{array}$ & brainstem edema with patchy $\mathrm{T} 2$ hyperintensity \\
\hline $\begin{array}{l}\text { Gianni } \\
\text { Coriolani } \\
\text { et al. [12] }\end{array}$ & 2020 & Italy & $\begin{array}{l}\text { Mycoplasma } \\
\text { pneumoniae }\end{array}$ & $\begin{array}{l}\text { Not } \\
\text { recorded }\end{array}$ & 7.5 & $\begin{array}{l}\text { Not } \\
\text { recorded }\end{array}$ & $\begin{array}{l}\text { Protein and } \\
\text { cell normal }\end{array}$ & $\begin{array}{l}8 \mathrm{~mm} \times 4 \mathrm{~mm} \text { in T2-FLAIR sequences in the left } \\
\text { thalamic area and the posterior left medulla } \\
\text { oblongata-spinal }\end{array}$ \\
\hline
\end{tabular}

${ }^{a}$ CSF Cerebrospinal fluid

In conclusion, we report a case of BBE caused by Salmonella Dublin, which needs to be brought to the attention of clinicians. When a patient is suspected of BBE caused by Salmonella Dublin,proper immunotherapy is particularly important. Of course, early antibiotic treatment of sepsis may control the disease and avoid severe encephalopathy .

\section{Abbreviations}

BBE: Bickerstaff's brainstem encephalitis; IVlg: Intravenous immunoglobulin; MRI: Magnetic resonance imaging; CSF: Cerebrospinal fluid

\section{Acknowledgements}

We would like to thank the patient for his participation in this study.

\section{Authors' contributions}

J X: case description, acquisition of data, analysis, and interpretation. T Z: acquisition of data, analysis, and interpretation. $T$ L: critical revision of the manuscript for important intellectual content. The author(s) read and approved the final manuscript.

\section{Funding}

None.

\section{Availability of data and materials}

All data analysed during this study are included in this manuscript.

\section{Declarations}

Ethics approval and consent to participate Not applicable.

\section{Consent for publication}

The patient gave written consent for their personal or clinical details along with any identifying images to be published in this study.

\section{Competing interests}

J. Xie reports no disclosures.

T. Zhang reports no disclosures.

T. Liu reports no disclosures.

Received: 20 October 2020 Accepted: 10 May 2021

Published online: 15 May 2021

References

1. Hughes RA, Newsom-Davis JM, Perkin GD, Pierce JM. Controlled trial prednisolone in acute polyneuropathy. Lancet. 1978;2:750-3.

2. Feasey NA, Dougan G, Kingsley RA, et al. Invasive non-typhoidal salmonella disease: an emerging and neglected tropical disease in Africa. Lancet. 2012; 379(9835):2489-3499.

3. GBD 2017. Non-Typhoidal Salmonella Invasive Disease Collaborators. The global burden of non-typhoidal salmonella invasive disease: a systematic analysis for the Global Burden of Disease Study 2017. Lancet Infect Dis. 2019;19(12):1312-24.

4. Gordon MA. Salmonella infections in immunocompromised adults. J Infect. 2008;56(6):413-22

5. Selander RK, Smith NH, Li J, et al. Molecular evolutionary genetics of the cattle-adapted serovar Salmonella Dublin. J Bacteriol. 1992;174(11):3587-92.

6. Taylor DN, Bied JM, Munro JS, et al. Salmonella dublin infections in the United States, 1979-1980. J Infect Dis. 1982:146(3):322-7.

7. Tagawa Y, Yuki N. Bickerstaff's brainstem encephalitis associated with shingles. J Neurol. 2000;247:218-9.

8. Rho Yl. Overlapping Guillain-Barré syndrome and Bickerstaff's brainstem encephalitis associated with Epstein Barr virus. Korean J Pediatr. 2014;57(10): 457-60. 
9. Koga M, Kusunoki S, Kaida K, et al. Nationwide survey of patients in Japan with Bickerstaff brainstem encephalitis: epidemiological and clinical characteristics. J Neurol Neurosurg Psychiatry. 2012;83:1210-5.

10. Kikuchi M, Tagawa Y, Iwamoto H, Yuki N. Bickerstaff's brainstem encephalitis associated withlgG anti-GQ1b antibody subsequent to Mycoplasmapneumoniae infection: favourable response to immunoadsorption therapy. J Child Neurol. 1997;12(6):403-5.

11. Steer AC, Starr M, Kornberg AJ. Bickerstaff brainstem encephalitis associated with mycoplasma pneumoniae infection. J Child Neurol. 2006;21(6):533-4.

12. Coriolani $G$, Ferranti $S$, Squarci $G$, et al. A case of Bickerstaff encephalitis associated with mycoplasma pneumoniae infection. Neurol Sci. 2020;41(6): 1605-6.

13. Hussain AM, Flint NJ, Livsey SA, Wong R, Spiers P, Bukhari SS. Bickerstaff's brainstem encephalitis related to campylobacter jejuni gastroenteritis. J Clin Pathol. 2007;60(10):1161-2

14. Mori M, Koga M, Yuki N, et al. Bickerstaff's brainstem encephalitis after an outbreak of campylobacter jejuni enteritis. J Neuroimmunol. 2008;196(1-2): 143-6.

15. Kanzaki A, Yabuki S, Yuki N. Bickerstaff's brain stem encephalitis associated with cytomegalovirus infection. J Neurol Neurosurg Psychiatry. 1995;58:260-1.

16. Wali GM. Bickerstaff's brainstem encephalitis associated with typhoid fever. Postgrad Med J. 1991;67:1011-2.

17. Sheng B, Ho WS, Lau KK, et al. Bickerstaff's brainstem encephalitis complicating Salmonella Paratyphi an infection. J Neurol Sci. 2011;302:108-11.

18. Odaka M, Yuki N, Yamada M, et al. Bickerstaff's brainstem encephalitis: clinical features of 62 cases and a subgroup associated with Guillain-Barré syndrome. Brain. 2003;126:2279-90.

19. Weidauer S, Ziemann U, Thomalske C, et al. Vasogenic oedema in Bickerstaff'S brainstem encephalitis:a serial MRI study. Neurology. 2003;61(6): 836.

20. Saito K, Shimizu F, et al. Blood-brain barrier destruction determines Fisher/ Bickerstaff clinical phenotypes: an in vitro study. J Neurol Neurosurg Psychiatry. 2013;84:756-65.

21. Overell JR, Hsieh ST, et al. Treatment for fisher syndrome, bickerstaff's brainstem encephalitis and related disorders. Cochrane Database Syst Rev. 2007;24(1):CD004761.

\section{Publisher's Note}

Springer Nature remains neutral with regard to jurisdictional claims in published maps and institutional affiliations.

Ready to submit your research? Choose BMC and benefit from:

- fast, convenient online submission

- thorough peer review by experienced researchers in your field

- rapid publication on acceptance

- support for research data, including large and complex data types

- gold Open Access which fosters wider collaboration and increased citations

- maximum visibility for your research: over $100 \mathrm{M}$ website views per year

At $\mathrm{BMC}$, research is always in progress.

Learn more biomedcentral.com/submissions 